\title{
AUGMENTED REALITY DALAM PROSES DESAIN ARSITEK MASA DEPAN
}

\author{
Benediktus Yosef Arya Wastunimpuna ${ }^{1 *}, 2$, LMF Purwanto ${ }^{2}$ \\ 1. Program Studi Rekayasa Infrastruktur Dan Lingkungan, Fakultas Ilmu Dan Teknologi Lingkungan, Universitas \\ Katolik Soegijapranata, Semarang \\ 2. Program Studi Doktor Arsitektur Digital, Fakultas Arsitektur Dan Desain, Universitas Katolik Soegijapranata, \\ Semarang
}

*Correspondent Author: arya_wastunimpuna@unika.ac.id

TgI masuk naskah: 16-06-2021 • Tgl review I: 21 \& 25-07-2021 • Tgl revisi: 02-08-2021• Tgl review II: 07 \& 08-08-2021 Tgl terbit 06-09-2021

DOI: $10.24167 /$ joda.v1i1.3494

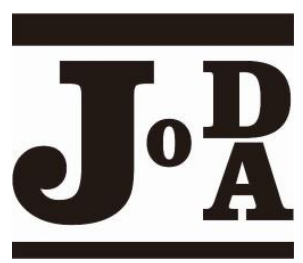

Abstrak:

Dunia arsitektur sedang mengalami sebuah tekanan terkait hasil karya dari para arsitek yang secara kuantitas sudah banyak namun dinilai kurang secara kualitas. Hal ini disebabkan karena dalam proses desain yang dilakukan oleh arsitek ditemukan gap yang cukup lebar antara konsep dengan praktek perancangannya. Oleh karena itu banyak arsitek yang mulai melirik dunia digital terutama augmented reality sebagai media yang dapat membantu proses mendesain. Augmented Reality memang memiliki kelebihan dalam menyajikan visual 3D yang sangat berguna bagi dunia arsitektur yang juga bermain dengan visual . Namun hingga sekarang augmented reality masih hanya diaplikasikan sebagai media informasi digital pada bangunan yang telah terbangun. Padahal jika melihat perkembangannya teknologi ini mampu untuk bermanfaat lebih dari itu. Sehingga tujuan dari penelitian ini adalah menganalisa dan mengindikasikan potensi penggunaan augmented reality pada proses desain seutuhnya. Metode yang digunakan adalah literature review dengan mencari literatur yang relevan kemudian melakukan sintesi analisanya. Dan pada akhir penelitian ditemukan bahwa augmented reality tidak hanya berfungsi sebagai media informasi dari hasil desain akan tetapi dapat ditempatkan dalam semua tahapan desain yaitu analisa, sintesis dan evaluasi.

Kata Kunci: Augmented Reality, Proses Desain, Arsitek, Arsitektur 


\section{Pendahuluan}

Arsitek adalah profesi yang selalu ikut serta dalam euforia perkembangan teknologi khususnya pada perkembangan komputer atau digital. [1] Hal ini disebabkan karena dunia arsitektur bergaul erat dengan ranah visual yang mampu ditunjang dengan penggunaan teknologi komputer. Sejak awal ditemukannya sketchpad pada tahun 1963 yang dirancang oleh Ivan Sutherland, komputer menjadi alat bantu dalam menggambar. [2] Dan lalu beriringan dengan hal tersebut berikutnya bermunculan teknologi seperti CAD / CAM dan juga hingga bermunculan software-software simulasi. Komputer menjadi alat menganalisa sebuah permasalahan yang ditemukan dalam desain. [3] Seperti pada tahun 1990, Frank Gehry menggunakan CATIA dalam proses mendesainnya. Digital atau komputer memberikan pemaknaan baru dalam ruang, yaitu bahwa ruang tidak lagi terbatas dengan hal-hal tertentu dan imajinasi dapat berkembang sangat luas. Penggunaan media digital, teknologi dan internet dalam dunia desain dan konstruksi salah satu pencapain paling penting dalam sejarah perkembangan arsitektur. [4]

Beberapa saat belakangan ini dunia arsitektur sedang mengalami sebuah kritikan. [5] Dimana dengan jumlah orang yang berprofesi sebagai seorang arsitek sekarang sangat banyak namun ternyata karya yang dihasilkan dianggap belum maksimal. Banyak bangunan hasil arsitek yang dianggap belum mampu untuk tepat secara guna dan lebih bersifat estetis saja. Padahal merunut dari awal berkembangnya Vitruvius sudah menetapkan ada tiga unsur yang seharusnya muncul dalam setiap karya asitektur yaitu terkait dengan kekuatan (firmitas), kegunaan(utilitas) dan keindahan (venustas). [6] Dan seorang yang berprofesi sebagai seorang arsitek seharusnya adalah mereka yang mampu menyelaraskan ketiga hal ini dalam sebuah karya arsitektur untuk menjawab permasalahan yang ditemukan. Namun ternyata dalam pelaksanaannya masih banyak arsitek yang berat sebelah pada satu atau dua unsur tertentu saja. Hal ini diakibatkan adanya gap antara konsep dengan permasalahan nyata yang seharus diselesaikan seorang arsitek.

Dan digital dirasakan sebagai penyelesaian masalah yang dapat diandalkan dalam menyelesaikan permasalahan ini. Banyak arsitek yang terus mencari teknologi-teknologi apa yang bisa digunakan untuk membuat desain mereka semakin membumi dengan kebutuhan penyelesaian masalah yang aktual. Salah satunya adalah mulai diliriknya media informasi digital yaitu augmented reality. Augemented reality (AR) adalah bagian dari ranah digital yaitu cyberspace bersama dengan virtual reality (VR). Namun terdapat perbedaan yang signfikan yaitu bahwa AR adalah penambahan informasi virtual ke dalam dunia nyata sedangkan VR sebaliknya adalah pengguna masuk ke dalam dunia virtual yang telah dirancang sebelumnya. [7]

Augmented reality (AR) adalah sebuah media informasi $3 d$ yang mampu menghadirkan visual $3 d$ tersebut ke lingkungan di sekitar pengguna dengan menggunakan sistem tracking. [8] Dalam pengaplikasiannya pada kerja seorang arsitek kini AR tidak hanya digunakan sebagai media presentasi terhadap klien. AR juga digunakan sebagai media informasi dalam perancangan karena mampu memberikan berbagai informasi terkait hasil analisa dan simulasi yang dilakukan pada sebuah bangunan. Beberapa penelitian terakhir mengenai Augmented Reality menangkap bahwa yang membedakan teknologi ini dengan VR pada irisannya dengan dunia arsitektur adalah bahwa AR diaplikasikan pada bangunan yang sudah jadi. Sedangkan jika VR diaplikasikan pada sebuah simulasi bangunan yang masih baru akan dibangun. Namun jika melihat tren yang muncul dalam perkembangan teknologi $A R$ sepertinya tidak hanya bisa diaplikasikan dalam tahap setelah bangunan jadi saja.

Oleh karena itu melalui penelitian ini mencoba untuk menemukan konsep baru dari penerapan teknologi augmented reality dalam dunia arsitektur. Mencoba mencari potensi lain dari sekedar hanya menjadi media informasi digital pada sebuah bangunan yang sudah jadi pada desain arsitektur. Sehingga nantinya akan dapat membantu menjawab permasalahan terkait gap antara konsep dengan permasalahan nyata dalam dunia arsitektur. Sebagai media informasi yang menyatukan dunia digital ke dalam dunia nyata AR diharapkan dapat menjawab setiap permsalahan yang selama ini mungkin belum terjawab oleh cara-cara konvesional dalam proses desain arsitektur. Dan mungkin saja akan menjadi sebuah profesi baru yang merubakan percabangan adri profesi arsitek yang harus beradaptasi dengan pesatnya perkembangan digital. Semua hal itu akan coba disintesiskan berdasarkan literatur yang sudah ditemukan. 


\section{Tinjauan Pustaka}

\section{Proses Desain Arsitektur}

a. Perencanaan

Terdapat sebuah proses dalam proses desain arsitetur sebelum perancangan yaitu perencanaan. Yang memiliki makna yaitu sebuah sarana untuk mengubah pemikiran dan persepsi mengenai lingkungan sekitar atau permasalahan yang ada ke dalam sebuah rencana yang sudah ditetapkan agar dapat dilaksanakan. [9] Terdapat beberapa kegiatan dalam sebuah perencanaan yaitu : [10]

i. Idettification, melakukan indentifikasi komponen penunjang dari sebuah objek pembangunan.

ii. Study, melakukan pencarian hubungan antara berbagai faktor yang memiliki kaitan dan ada dampak yang spesifik terhadap permasalahan.

iii. Determination, mengambil sebuah ketentuan yang tepat terhadap sebuah faktor yang berpengaruh terhadap faktorfaktor lainnya.

iv. Prediction, membuat sebuah perkiraan bagaimana sebuah faktor akan berubah menjadi sesuatu yang lebih baik.

v. Action, berdasarkan perkiraan yang telahd buat kemudian melakukan tindakan yang harus dilakukan dalam menyelesaikan masalah.

Terdapat pula beberapa teori tentang perencanaan yaitu : [11]

- Theory In Planning, sebuah pendekatan teori yang dipakai dalam sebuah perencanaan yang terkait dengan substansi atau objeknya.

- Theroy For Planning, sebuah pendekatan teori yang terkait konteks sosial yang akan menunjukan kondisi seharusnya masyrakat dan perencanaan di masa yang akan datang.

- Theory Of Planning, adalah pendekatan yang dipilih untuk mendukung berbagai kebijakan dalam sebuah perencanaan baik dari proses atau prosedur dan juga terkait inti perencanaanya.

b. Evolusi Perancangan

Terdapat 3 tahapan waktu dalam perancangan yaitu : [12]

i. Fase Crafmantship

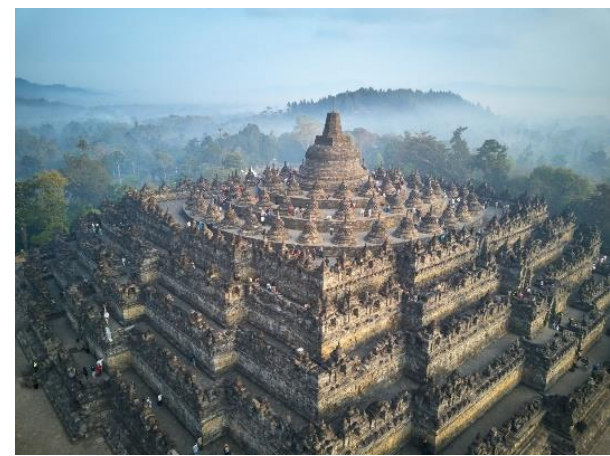

Gambar 1.candi Borobudur sebaga contoh fase craftmanship [13]

Sebuah fase proses perancangan yang dilakukan dengan mengandalkan kreativitas dan kesenian dari pihak perancang. Dimana berarti pihak perancang adalah pribadi yang memiliki kemampuan yang sudah terlatih. Prosesnya adalah dengan terus melakukan penyempurnaan terhadap proses perancangan sebelumnya. Sehingga yang disebut dalam tahap akhir adalah pada fase ini adalah hasil dari segala penyempurnaan yang telah dilakukan. Bangunan-bangunan yang masuk dalam fase ini biasanya adalah candi dan juga bangunan tradisional. (Perhatikan Gambar 1.)

ii. Fase Metode Gambar

Fase dimana perancangan dilakukan dengan menggunakan gambar. Produksi perancangan dipisahkan dalam beberapa bagian. Proses pengerjaan akan lebih efektif dan lebih sistematis. Karena pekerjaan tidak bersifat dibuat dulu baru diperbaiki melainkan sudah ada perencanaan terlebih dahulu sebelumnya hingga kemudian baru ada proses perancangan.

iii. Fase Design Method

Terbagi menjadi dua bagian yaitu : [14]

- Metode Tradisional / Blackbox

Metode dimana seorang perancang mendapatkan ide dalam meracangnya darimana saja. Susah untuk dapat dijelaskan dan dijabarkan asalnya. Tidak dapat dikritik dan waktu produksi tergantung dari si perancang.

- Metode Rasional/ Glassbox

Metode dimana seorang perancang melakukan perancangan nya dengan ide-ide yang logis. Konsep dan ide perancangan bukan berasal dari hal 
yang tidak masuk akal dan tiba-tiba melainkan ada langkah-langkah yang telah dipersiapkan. Proses analisa dilakukan secara menyeluruh dan juga ada pengujian untuk menguji analisa yang ditemukan. Hasil perancangannya bukan sesuatu yang hanya coba-coba melainkan telang sangat matang dirancang.

c. Proses Desain

Berikut ini merupakan aspek-aspek yang terdapat pada proses desain seorang arsitek yaitu : [15]

- Gagasan/Ide

Gagasan adalah hasil dari sebuah proses menerjemahkan ruang dan juga mendapatkan pemahaman arsitektural akan sebuah permsalahan desain.

- Tema

Tema adalah sebuah gagasan yang sudah melalui beberapa proses. Tema berfungsi sebagai ruang lingkup untuk imajinasi dari seorang perancang dimana akhirnya mampu menemukan gagasan. Dimana pada akhirnya teman adalah gagasan yang telah digabungkan dengan sudut pandang arsitektural.

- Konseptualisasi

Adalah usaha dalam mendapatkan atau menggapai konsep. Proses yang ada adalah penetapan karakter khas perancang yang merupakan hasil pemahaman dari perancangn atas teman perancangan. Dalam penentuan konsep acuannya adalah kembali ke gagasan. Konsep disajikan dalam format tulisan dan juga sketsa ide.

- Masalah

Adalah gagasan atau tema yang disampaikan dengan batasan batasan aturan ilmiah dalam berpikir yang dilakukan dengan sangat ketat.

- Preseden

Dalam dunia perancangan preseden meiliki makna sebuah contoh yang sudah dibuktikan perumusan perancangan arsitektur.

- Asas Rancang

Asas dalam dunia merancang adalah seperti landasan teori yang dimiliki oleh si perancang dan harus ada. Hal ini bertujuang agar menunjang keilmiahan dari perancangan. Sehingga nantinya tema dan gagasan yang diangkat akan terjamin keobjektifannya.

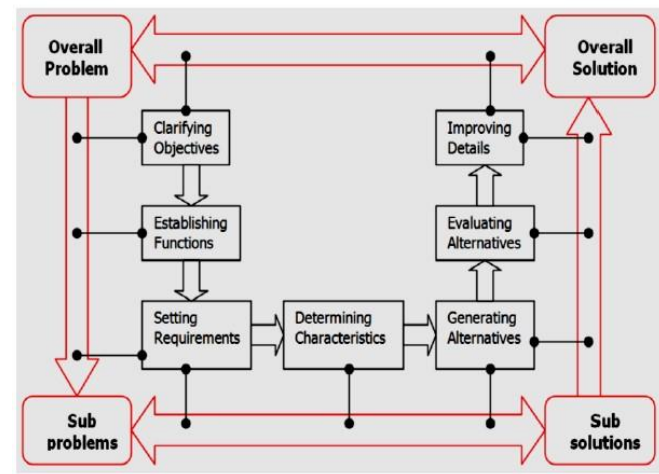

Gambar 2. Proses Perancangan Menurut Nigel Cross [15]

Secara garis besar proses perancangan dari Nigel Cross terbagi menjadi 4 komponen pokok uraian yaitu : [16] (Perhatikan Gambar 2.)

- Clarifying Objective, menyusun atau menetapkan konsep umum dari awal sampai akhir.

- Establishing Function, menyusun dan menetapkan kinerja dari obyek yang dirancang.

o Setting Requirements, membuat tampilan dari objek yang akan dirancang.

- Determining Characteristics, membuat sebuah karakteristik yang kuat dan khas dari objek rancangan.

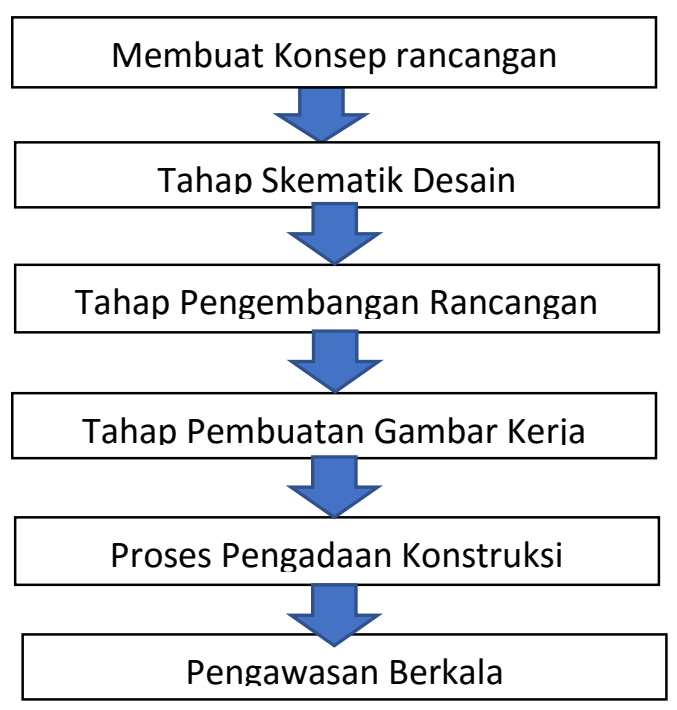

Gambar 3. Proses Kerja Seorang Arsitek Menurut Ikatan Arsitektur Indonesia [17] 
Lalu Ikatan Arsitek Indonesia selaku badan keprofesian arsitek di Indonesia mengeluarkan pemahaman mengenai proses kerja seorang arsitek meliputi :

1. Pembuatan Konsep, sebelum perancangan dilaksanakan harus ada sebuah kejelasan informasi mengenai pengguna jasa dengan cara melakukan pemeriksaan menyeluruh terhadap itu semua. Lalu diikuti dengan melakukan analisa terhadap data dan informasi yang ditemukan tersebut. Analisa yang dilakukan menghasilkan program rancangan dan konsep rancangan.

2. Tahap Skematik Desain, adalah proses setelah pembuatan konsep rancangan yaitu mebuat gambar-gambar eksplorasi bentuk. Eksplorasi yang dilakukan harus sesuai dengan konsep yang telah ditentukan.

3. Tahap Pengembangan Rancangan, adalah tahap setelah proses konsep dan eksplorasi bentuk terlalui maka pada tahap berikutnya seorang arsitek mulai menyusun perkiraan dan detail teknis konstruksi yang harus dilakukan.

4. Tahap Pembuatan Gambar Kerja. adalah tahap pembuata gambar kerja yang teknis dan terperinci sehingga mendapatkan kejelasan mengenai proses pelaksanaan konstruksi.

5. Proses Pengadaaan Kosntruksi

Tahap seorang arsitek menyusun dokumen pelelangan berdasarkan gambar kerja yang telah dibuat. Hal ini dilakukan dalam rangka mendapatkan penawaran terbaik sehingga konstruksi dapat dilaksana dengan baik dan benar.

6. Pengawasan Berkala, adalah tahapan seorang arsitek melakukan pengawasan dan peninjauan terhadap hasil rancangan secara teratur dan berkala.

\section{Augmented Reality}

Augmented Reality adalah tampilan segala informasi yang ada pada waktu yang nyata yang digabungkan atau dimasukan ke dalam dunia nyata sesungguhnya.[18] Ini yang membedakannya dengan virtual reality (VR) yaitu jika VR mencoba menggantikan dunia nyata dengan dunia maya. Pemakai akan masuk ke dunia virtual yang sudah dirancang. Peranngkat AR membutuhkan beberapa teknologi seperti :

1. GPU / Graphic Processing Unit

2. Perangkat proyeksi

3. Sensor

4. Sistem audio

5. Sistem pengkategorian atau pendekteksi objek

6. Sistem operasi

7. Komunikasi Wireless

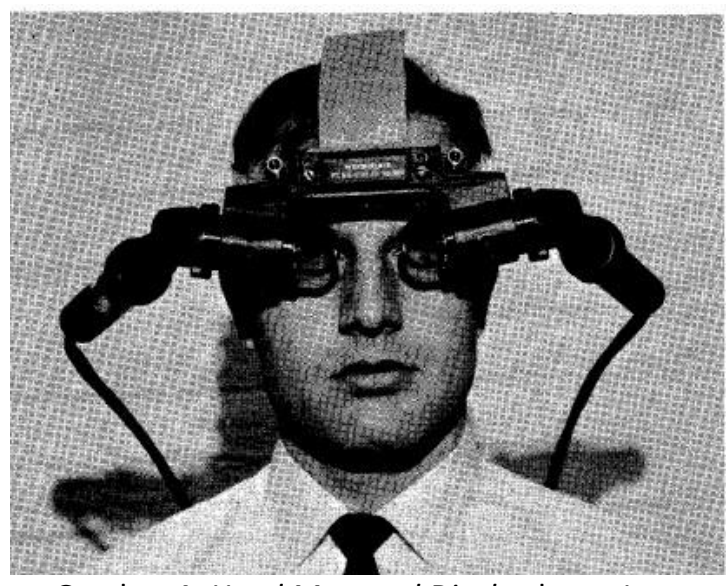

Gambar 4. Head Mounted Display karya Ivan Sutherland [19]

Ivan Sutherland adalah seseorang yang terkenal lebih dahulu dengan temuannya pada tahun 1963 yaitu Sketchpad yang menjadi aplikasi tentang interaksi grafik pertama yang ada di dunia.Kemudian setelah pindah ke Harvard University pada akhirnya dia membuat sebuah teknologi yang menjadi cikal bakal dari augmented reality (AR) yaitu head mounted display (HMD).[20] (Perhatikan Gambar 4.) Walaupun terlihat kurang modern namun alat ini mampu untuk membentuk sebuah grafik tiga dimensi (3D) yang tampak seakan melapisi dunia nyata yang ada.Penemuan ini berangkat dari rasa penasarannya Ivan terhadap gaya yang bekerja pada sebuah objek yang tidak dapat dilihat mata telanjang. Menurut Ivan teknologi komputer lah yang dapat menyelesaikannya. Namun display dari layar komputer dirasa kurang nyata dan presisi sehingga muncul pemikiran untuk membuat display yang langsung sejajar dengan mata manusia. Dalam HMD ini menggunakan sebuah mechanical tracker dan sebuah ultrasonic tracker. Pada generasi awal ini gambar wireframe yang dihasilkan secara realtime masih sangat sederhana.

Kata kunci dari augmented reality (AR) adalah pada augmentasi yang dilakukan. Augmentasi mengacu pada aspek-aspek yang mempengaruhi sistem 
sensorik dari manusia sebagai pengguna. [21] AR harus mampu untuk mengetahui lebih tentang konten virtual dan dunia nyata. Dan harus mengetahui dimana posisi sebuah objek berada dalam ruang (registrasi) dan mengikuti kemana sebuah objek bergerak (tracing). AR berbeda dengan efek yang dihasilkan pada film untuk menyatukan dunia virtual dengan dunia nyata karena didasarkan pada aspek berikut ini:

1. Berada dalam 3D

Berbeda dengan film AR melakukan semua penggabungan kontan digital dengan dunia nyata dalam 3D langsung.

2. Terjadi dalam waktu yang sesungguhnya Dalam film semua merupakan hasil rekaman sedangkan AR menunjukan langsung keadaan asli dalam waktu yang sesungguhnya.

3. Interaktif

Saat menonton film penonton hanya pasif melihat tampilan sedangkan pada AR pengguna bisa berinteraksi

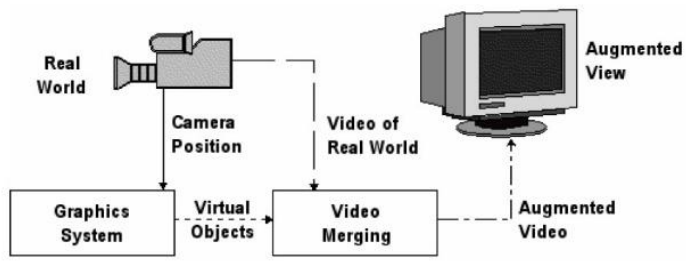

Gambar 5. Augmented Reality System [22]

Terdapat beberapa komponen yang diperlukan dalam perancangan augmented reality yaitu : (Perhatikan Gambar 5.)

\section{- Komputer}

Komputer dalam sistem perancangan AR adalah sekumpulan perangkat yang akan mengatur seluruh rangkaian aksi yang akan dilakukan oleh aplikasi. [22] Sehingga keberadaan komputer ini tergantung pada fungsi apa yang akan dijalankan oleh aplikasi. Semakin rumit yang harus dijalankan maka membutuhkan komputer dengan kemampuan yang lebih baik.

- Head Mounted Display

Merupakan sebuah perangkat keras yang berfungsi sebagai pengganti monitor atau menjadi display dari hasil penambahan gambar $3 d$ pada dunia nyata. Sehingga gambar terasa nyata karena langsung tepat diantarkan ke depan mata pengguna. Gambar 3D yang dihasilkan berangkat dari pengolahan scene generator yang merender tampilan.
- Marker

Marker secara garis besar adalah sebuah bentuk persegi hitam dengan bagian tengah putih yang menjadi bagian dari sistem tracking aplikasi. Karena marker maka komputer akan mampu mengenali objek dan menghasilkan gambar 3D. Oleh karena itu pula penggunaan marker pada AR tergantung pada library yang digunakan. [23] Langkah pertama dalam pendeteksian marker adalah komputer mendapatkan tangkapan video oleh kamera yang berasala dari dunia nyata di sekitar kita. Lalu berikutnya aplikasi yang terdapat pada komputer akan melacak setiap infomrasi digital dalam bentuk video yang terdeteksi pada marker. Setelah kotak marker didapatkan maka aplikasi akan memperhitungkan posisi kamera dengan marker sesuai dengan persamaan yang ditetapkan. Berikutnya disaat kamera telah mengenali posisi dari marker maka akan menggambarkan model yang akan diletakan di atas marker.

\section{Implikasi Augmented Reality Dalam Desain} Arsitektur

Sebelum pembahasan lebih lanjut mengenai implikasi Augmented Reality (AR) dalam desain arsitektur, perlu diperhatikan adanya perbedaan yang mendasar dengan Virtual Reality (VR). Yang dimana keduanya merupakan bagian dari ranah digital cyberspace. Secara ringkas perbedaan paling dapat dilihat adalah bahwa AR menggabungkan dunia nyata dengan dunia asli dengan dunia maya adalah dengan menambahkan informasi dari dunia maya itu ke dalam dunia asli/ nyata di sekitar penggunanya. Sedangkan pada VR dunia asli/nyata yang akan ditampilkan dan masuk ke dalam dunia maya yang sudah dibuat terlebih dahulu. [24] Perbedaan ini tentu akan berpengaruh besar disaat mencoba mencari implikasi teknologi ini pada desain arsitektur. 


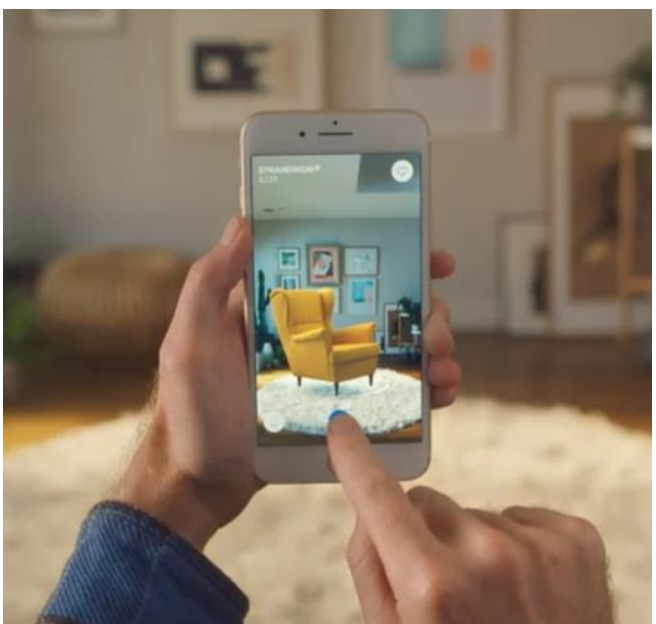

Gambar 6. IKEA Place [25]

AR pada fase perkembangannya yang beririsan dengan dunia desain arsitektur memang sudah terdapat berbagai inovasi. Beberapa software seperti IKEA Place dapat digunakan oleh pembeli produk IKEA untuk mencoba mengaplikasikan produk mebel yang akan dibeli dengan ruangan di rumahnya. (Perhatikan Gambar 6.) Sehingga calon pembeli ini dapat menilai dan menemukan kecocokan antara produk tersebut dengan ruangan yang akan diisi.
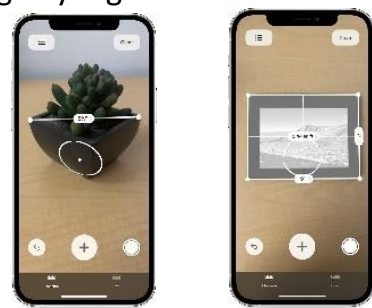

Gambar 7. Measure Apps for IOS [26]

Ada juga measure apps for IOS yang dapat digunakan untuk mengganti alat pengukuran. (Perhatikan Gambar 7.) [25] Aplikasi ini mampu untuk membantu dalam proses pengukuran dimensi. Seorang arsitek tidak perlu membawa lagi meteran untuk mengukur. Beberapa software ini menunjukan bahwa dalam arsitektur AR memang cenderung lebih membantu dalam pemberian informasi sebuah karya desain yang sudah terbentuk atau sudah ada. Berbeda dengan VR yang dalam beberapa software yang ditemukan lebih kepada mensimulasi sebuah bangunan baru yang belum terbentuk. [27]

\section{Implikasi Augmented Reality Dalam Dunia Konstruksi}

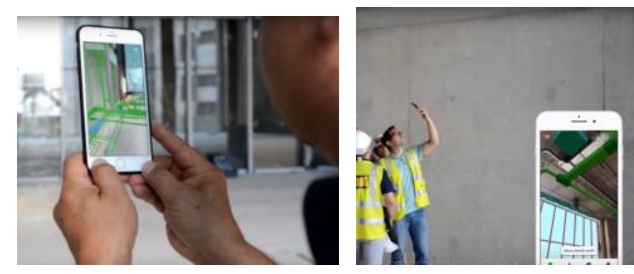

Gambar 8. Gamma AR [28]

Dalam dunia konstruksi AR banyak digunakan dalam pengolahan Building Information Modelling (BIM). Beberapa software yang telah digunakan seperti Gamma AR. (Perhatikan Gambar 8.) Gamma AR adalah sebuah software yang terhubung langsung dengan BIM. Software ini digunakan untuk mendeteksi kesalahan fungsi dari konstruksi pada bangunan. Deteksi tersebut langsung akan masuk ke sistem yang akan dapat dibaca oleh seluruh pekerja dalam sebuah proyek konstruksi. Hal ini memudahakan seorang perancang dalam medeteksi kesalahan pada hasil karyanya.

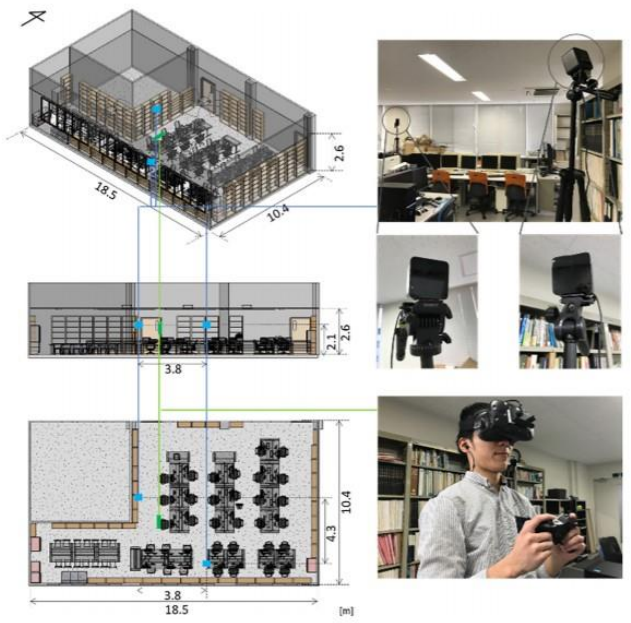

Gambar 9. Studi Termal Pada Interior Ruangan [29]

Berdasarkan literature review ditemukan sebuah studi yang dilakukan oleh Tomohiro Fukuda dengan timnya pada tahun 2019. (Perhatikan Gambar 9.) Studi atau penelitian ini bertujuang untuk merancang sebuah prototype sistem AR yang mampu berkolaobrasi dengan software simulasi thermal dan BIM. Dan dalam proses desain AR juga mampu dijadikan sebuah sumber informasi terkait kondisi thermal dari lokasi perancangan berada. Sebenarnya tidak hanya berkolaborasi dengan software simulasi termal namun juga dapat terhubung dengan big data seperti jika ingin mengambil data iklim suatu daerah untuk landasan penyusunan konsep rancangan. 
Melalui temuan ini pula AR juga dapat menemukan inti permasalahan yang akan coba diberikan solusinya dalam perancangan.

\section{Otomatisasi Dalam Arsitektur Dan Lahirnya Profesi Baru Arsitek}

Otomatisasi dalam dunia arsitektur menjadi perbincangan yang sangat hangat beberapa tahun ke belakang ini. Merupakan sebuah fase baru dari perkembangan irisan dari dunia arsitektur dengan digital setelah dahulu diawali oleh sketchpad karya Ivan Sutherland. [30] Perkembangan berikutnya dan masih hingga sekarang adalah bagaimana komputer sudah bukan lagi hanya menjadi alat namun juga memiliki kemampuan berpikir. Pengembangan Artificial Intelegence semakin luar biasa. Muncul beberapa ketakutan karena akan kehilangan profesi sebagai seorang arsitek atau pekerja bangunan. Namun menurut Wagner dalam setiap siklus kehidupan manusia akan dengan kreatif menemukan profesi baru untuk bertahan hidup. Begitu pula dengan profesi arsitek. Terdapat beberapa profesi baru yang akan muncul dalam dunia arsitektur sebagai seorang arsitek yaitu [31] :

1. Augemented Reality Architect

Sebuah profesi baru dimana seorang arsitek memiliki bantuan kemampuan visual yang lebih baik dengan memanfaatkan augmented reality. Dasar proses kreatif dalam profesi ini masih dimiliki oleh si arsitek.

2. Penyusun Al Untuk Software Arsitektur

Dalam waktu belakangan ini pengembangan software mengarah pada penggunaan aritifical intelegence di dalamnya. Hal itu juga terjadi pada perkembangan software arsitektur. Namun tentunya dalam proses penyusunannya selain diperlukannya seorang programmer yang handa akan tetapi juga membutuhkan pendapat dan pemikiran dari seorang arsitek.

3. Archeology Architect

Sebuah profesi baru dari seorang arsitek yaitu mencari data lama mengenai arsitektur yang nantinya tentu membutuhkan kemampuan analisa dari arsitek. Profesi ini adalah percampuran dari arsitek, programmer dan juga hukum. Dapat membantu mengatasi konflikkonflik yang terjadi mengenai klaim terhadap sebuah karya arsitektur atau langgam tertentu.

4. Automatictecture Assistant

Sebuah profesi baru yang diperkirakan muncul karena secanggih apapun teknologi pasti akan juga membutuhkan manusia dalam perawatan dan juga pengembangannya.

\section{Metode Penelitian}

Metode penelitian yang digunakan untuk penelitian ini adalah literature review. Yaitu dengan membuat sintesi hasil analisa dari artikel-artikel yang relevan terkait dengan topik yang akan dibahas. Dari hasil pencarian dan penganalisaan literatur akan coba dipertemukan antara proses desain seorang arsitek dengan teknologi augmented reality. Pada penelitian artikel yang dicari adalah terkait tentang:

1. Proses desain arsitek

Merumuskan dan mencari tahu tentang publikasi-publikasi ilmiah yang membahas mengenai proses desai dari seorang yang berprofesi sebagai aritek. Mencari sintesisnya sehingga mendapatkan tahapan-tahapan proses desain yang ada dan digunakan.

2. Augmented reality (AR)

Merumuskan dan mencari tahu mengenai augmented reality dalam temuan-temuan penelitian yang sudah terpublikasikan secara ilmiah. Mencoba mencari sintesis terkait pemikiran awal penemuan teknologi AR, sistem operasi utama dari penyusunan $A R$ serta komponen-komponen yang diperlukan.

3. Implikasi AR dalam desain arsitektur Merumuskan dan mencari tahu penelitianpenelitian yang sudah terpublikasi secara ilmiah mengenai mengenai irisan antara perkembangan teknologi augmented reality dalam dunia arsitektur

4. Otomatisasi Arsitektur

Merumuskan dan mencari tahu penelitianpenelitian yang sudah terpublikasi secara ilmiah mengenai otomatisasi yang sedang terjadi dalam dunia arsitektur dan dampak yang muncul karenanya.

\section{Pembahasan Hasil}

Hasil Sintesis Literatur Proses Desain Arsitek

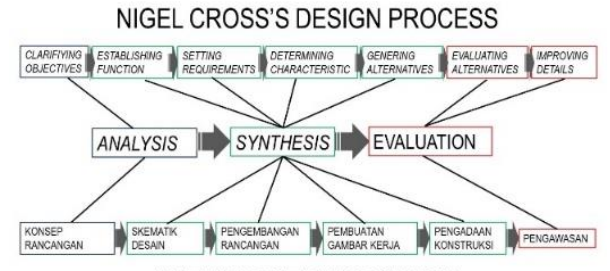

IKATAN ARSITEK INDONESIA

Gambar 10. Generalisasi Tahapan Perancangan [15] [17] 
Proses desain yang dikemukakan oleh Nigel Cross dan juga oleh Ikatan Arsitek Indonesia memiliki sebuah alur pemahaman yang sama. Dan ternyata jika diklasikasikan akan mendapatkan tiga urutan generalisasi yang telah dijabarkan oleh Bryan Lawon yaitu Analysis, Systhesis dan Evaluation. [32] Porsi terbesar dimiliki oleh tahapan synthesis dalam proses perancangan desain. Berikut ini adalah penjabaran dari ketiga tahapan dalam proses desain dan kebutuhan yang harus menjadi outputnya serta kebutuhan fungsi akan media penunjang:

a) Analysis

Pada tahapan ini diisi oleh tahapan mengindentifikasi masalah. Arsitek akan berusaha semaksimalkan mungkin untuk memahami segala informasi terkait objek desain dan juga mengenai perilaku penghuni. Output yang biasanya dikeluarkan adalah dalam bentuk program rancangan dan konsep rancangan. Tahapan ini biasanya juga disebut tahap perencanaan. Lalu kebutuhan untuk media yang dapat menunjang proses tahapan ini adalah media informasi yang dapat membantu memberikan informasi sekomplit-komplitnya sehingga dalam penyusunan program dan konsep perancangan mampu membaca masalah secara menyeluruh.

b) Synthesis

Pada tahapan ini proses desain yang berjalan adalah sebuah pencarian penyelesaian masalah. Setelah gagasan dan konsep ditemukan pada fase sebelumnya, di sini arsitek akan mulai bermain dengan eksplorasi bentuk. Lalu dari bentuk yang telah ditemukan adalah mulai memikirkan terkait bagaimana detail konstruksi dari objek perancangan. Dan berikutnya adalah pembuatan gambar kerja berdasarkan eksplorasi bentuk dan detail konstruksi yang telah dibuat.

c) Evaluation

Adalah tahapan dimana perancang melakukan evaluasi atau pengawasan secara berkala terhadap objek perancangan yang telah diciptakan. Yang dibutuhkan pada tahap ini adalah informasi terkini dan realtime mengenai kondisi objek perancangan.

\section{Hasil Sintesis Literatur Augmented Reality (AR)}

Konsep dasar dari perkembangan Augmented Reality adalah keterbatas indera penglihatan manusia terhadap gaya yang bekerja pada benda. Hal itulah yang menimbulkan Ivan Sutherland memiliki ide untuk menciptakan Head Mounted Display (HMD). Sehingga hal itu lah yang menjadi garis patokan dalam perkembangan ke depannya. AR bertujuan untuk memberikan manusia informasi lebih dari yang hanya bisa terlihat oleh mata manusia. Hal itu menekankan peran AR dalam perkembangan dunia profesi yang bermain dengan visual. Salah satunya adalah profesi arsitek. AR memungkinkan semua pengalaman visual itu muncul dan terasa nyata karena device yang digunakan sejajar dengan mata manusia.

Penampakan digital yang ditambahkan di dunia nyata itu muncul langsung di HMD yang langsung dipakai dan bukan melalui computer device yang tidak portabel. Hal ini sangat berperan dalam keluwesan pengguna saat ingin mendapatkan infomrasi dan melakukan kerja yang lain. AR mampu menampilkan berbagai informasi visual yang dibutuhkan tanpa hambatan namun memang dalam penyusunannya proses pengumpulan informasi melalui penelitianpenelitian yang ilmiah itu memiliki peran penting. Dengan menjaga bahwa informasi yang diberikan bersifat ilmiah teknolgi AR ini mampu membantu manusia dalam penemuan kebenaran dan pengetahuan. Selain itu pula secara sistem operasi yang perlu menjadi perhatian adalah bahwa AR merupakan sebuah teknologi yang bergantung pada sistem tracking yang baik. Sehingga dalam penyusunannya hal ini harus menjadi pemikiran dan membutuhkan spesifikasi lebih.

\section{Hasil Sintesis Implikasi Augmented Reality Dalam Proses Desain Arsitektur}

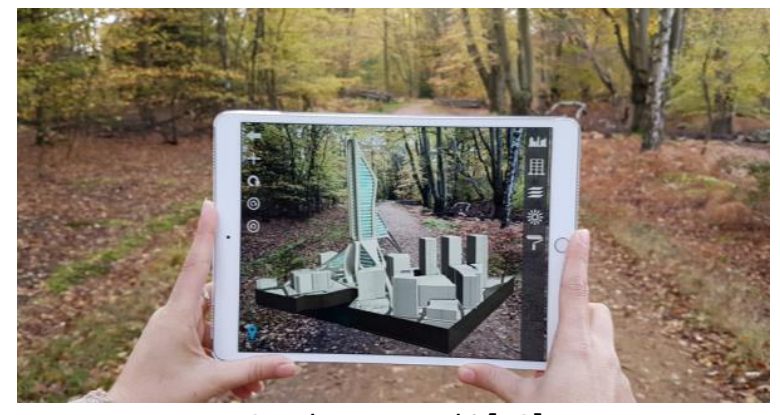

Gambar 11. ARki [18]

Dalam dunia arsitektur menurut Redyantanu [25] disebutkan bahwa augmented reality sudah sering digunakan dalam prosesnya. Perlu dibedakan terlebih dahulu mengenai konsep augmented reality dan virtual reality karena akan menentukan bagaimana teknologi ini digunakan. AR sering digunakan memang dalam sebuah desain yang sudah jadi. Desain yang sudah jadi ini kemudian akan ditambahkan informasi digital. Atau juga beberapa 
software seperti Morpholio AR Sketchwalk dan ARki (Perhatikan yang menunjang untuk memplotting hasil $3 d$ yang sudah dibuat ke dalam site yang akan digunakan.

Namun sebenarnya AR dengan potensi yang dimiliki tidak hanya terbatas pada hal tersebut. AR tidak hanya dapat digunakan untuk memberikan informasi tambahan disaat sebuah desain bangunan sudah jadi atau bahkan terbangun. Potensi yang dimiliki AR sebagai sebuah media visual juga mampu membantu dalam proses perencanaan dan perancangan seorang arsitek. Sehingga dapat dikatakan bahkan sebelum bangunan terbangun, AR dapat digunakan untuk membantu proses perencanaan dan perancangan. Hal itu dapat diuraikan seperti berikuti ini :

1. Analisa

Dalam tahap awal proses desain seorang arsitektur adalah tahap analisa. Di tahap ini seorang arsitek akan menganlisa masalah yang ada dalam rencana desain yang akan dilakukan. Sehingga posisinya tahap ini adalah tahapan dimana desain belum muncul. Penggalian informasi yang sangat banyak menjadi inti dalam tahapan ini. Dan augmented reality sebaga media digital yang menghasilkan informasi mampu diaplikasikan pada tahapan ini. Teknologi ini dapat digunakan dalam proses pengumpulan informasi mengenai tapak yang akan digunakan sehingga mampu membantu seorang arsitek memetakan permasalahan yang muncul. Berbagai software AR untuk mendapatkan informasi tentang topografi, dimensi tapak, kondisi iklim dan view ke tapak atau dari tapak sudah ada dan dapat digunakan baik berbayar mapun tidak. Dan dengan pengembangan Big Data dari berbagai bidang tentunya juga akan mempemudah untuk penyusunan sebuah software AR yang akan membantu proses analisa dalam desain seorang arsitek. Dengan informasi yang didapatkan dari $A R$ yang digunakan tentu akan menunjang dan meningkatkan kemampuan seorang arsitek menangkap permasalahan dalam desain.

2. Sintesa

Dalam tahap ini seorang arsitek akan mulai mencari penyelesaian masalahnya dalam bentuk desain. Diawali dengan mencoba mencari bentuk atau sering disebut sebagai tahap eksplorasi bentuk. Di tahapan ini sudah banyak software AR yang menyediakan fasilitas untuk seorang arsitek dapat bermain bentuk dan menampilkannya secara visual nyata bahkan dengan perbandingan 1:1 seperti Fologram. Bahkan dapat berinteraksi langsung serta melakukan perubahan dengan cepat dan real. Teknologi ini sangat membantu dalam tahap eksplorasi bentuk yang tentu jauh lebih efisien dari cara konvensional. Cara konvensional yang dimaksud adalah dengan pembuatan maket dan pembuatan model 3d di komputer. Selain lebih efektif tentu dengan visual yang lebih nyata dan interaktif seorang arsitek akan mampu memiliki keleluasaan lebih dalam mengeksplorasi bentuk yang diinginkan.

3. Evaluasi

Pada tahapan ini sebenarnya fungsi AR yang sudah sering ditemukan. Dimana bangunan sudah terealisasikan dan berikutnya melakukan fungsi perawatan dan evaluasi. Hal ini juga berkaitan erat dengan BIM. Beberap software seperti gamma AR sudah sering digunakan dalam proses ini. Membantu mengawasai dan mengevaluasi kinerja dari bangunan sehingga segala kendala yang muncul dapat segera teratasi.

\section{Hasil Sintesis Otomatisasi Dalam Arsitektur Dan Lahirnya Profesi Baru Arsitek}

Dalam perkembangannya sekarang otomatisasi dalam dunia arsitektur memang semakin terealisasi. Sudah banyak pekerjaan bangunan mulai menggunakan dan menggantikan peran manusia dengan peran digital seperti robot-robot pintar. Dan tidak terelakan hal itu menimbulkan sebuah keharusan untuk beradaptasi dengan baik. Salah satu wujud adaptasi itu adalah munculnya profesi baru dalam arsitek seperti Aumgented Reality Architect. Dan jika menilik dari apa yang sudah diuraikan di atas kemungkinan ini sangat besar adanya di masa depan. Hal ini karena teknologi AR sekarang dapat membantu setiap proses desain dari seorang arsitek. Kalau dalam metode terdahulu seorang arsitek dalam tiap proses desain harus melakukan secara manual dan sangat tidak efisien. Sekarang dengan menggunakan smartphone saja seorang arsitek dapat memulai proses desainnya. Hal ini membawa keuntungan sehingga seorang arsitek dapat berfokus pada konten desainnya dan tidak diribetkan dengan teknisnya.

\section{Kesimpulan}

Proses mendesain seorang arsitek dapat diklasifikasikan menjadi tiga tahapan utama. Tahapan 
itu adalah analysis, synthesis dan evaluation. pada tahap analysis seorang arsitek akan melakukan pendekatan terhadap permasalahan perancangan. Lalu pada tahapan synthesis, seorang arsitek akan mulai melakukan aksi dalam pencarian penyelesaian masalah yang muncul berangkat dan berlandaskan dari gagasan dan konsep rancang yang telah ditemukan sebelumnya. Pada tahap ini pula akan terjadi proses mendetailkan konstruksi dari hasil rancangan serta proses produksi gambar kerja. Dan di tahap akhir adalah evaluation dimana seorang arsitek mengevaluasi hasil karyanya.

Berdasarkan studi literature yang telah ditemukan bahwa terdapat software augmented reality baik yang masih berupa prototype maupun sudah ada di pasaran. Dan berdasar hasil analisa yang dilakukan dengan mempertemukan antara kebutuhan dari tiap tahapan desain dengan fungsionalitas dari AR, disimpulkan bahwa AR mampu memberikan solusi dan informasi pada setiap proses perancangan. Untuk tahapan analyisis, beberapa software AR yang ditemukan dalam literatur menunjukan bahwan $A R$ dapat memberikaninformasi mengenai site dan juga kondisi termal setempat. Lalu untuk tahapan synthesis sudah ada beberapa software AR yang ditemukan di pasaran yang mampu mmebantu dalam eksplorasi bentuk dan juga perumusan konstruksi bangunan. Dan yang terakhir untuk evaluasi, sudah terdapat software AR di pasaran yang mampu berkolaborasi dengan BIM untuk mempermudah evaluasi konstruksi bangunan.

Lalu juga dapat disimpulkan bahwa AR berperan besar dalam membuat tahapan desain seorang arsitek menjadi lebih efisien karena dapat memotong durasi waktu dalam sebuah tahapan mendesain. Selain itu AR juga mampu membantu mendetailkan secara menyeluruh bagi seorang arsitek dalam memahami objek perancangannya. Sehinga dalam proses desain arsitektur di masa depan yang melibatkan penggunaan digital terutama AR dapat dilakukan dengan tahapan yang lebih efektif dan efisien. Serta juga mampu meningkatkan kualitas dari setiap hasil karya yang tercipta dari seorang arsitek.

Berdasarkan literatur juga disebutkan bahwa ada kemungkinan muncul sebuah profesi baru yaitu augmented reality architect. Sebuah profesi yang mengkhususkan seorang arsitek yang menggunakan teknologi AR dalam proses desainnya. Dan menurut penelurusan yang dilakukan itu mungkin terjadi. Karena dengan kemajuan yang ada sekarang dan irisan yang semakin besar antara digital dan arsitektur ,seorang arsitek harus terus mampu beradaptasi ke metode atau proses desain yang lebih efektif dan tepat.

\section{Pustaka}

[1] P. Satwiko, Arsitektur Digital. Yogyakarta: Penerbit Universitas Atma Jaya Yogyakarta, 2010.

[2] A. Utterson, "Early Visions of Interactivity :," Leonardo, vol. 46, no. 1, pp. 67-72, 2013.

[3] S. Loumer, "Digital Architecture and Intelligent Buildings: A Suitable Approach to Proper Implementation of Sustainable Development Components in the Third Millennium," Curr. World Environ., vol. 10, no. Special-Issue1, pp. 74-81, 2015, doi: 10.12944/cwe.10.special-issue1.11.

[4] R. Oxman, "Digital architecture as a challenge for design pedagogy: theory, knowledge, models and medium," Des. Stud., vol. 29, no. 2, pp. 99-120, 2008, doi: 10.1016/j.destud.2007.12.003.

[5] A. Tzonis, "A framework for architectural education," Front. Archit. Res., vol. 3, no. 4, pp. 477-479, 2014, doi: 10.1016/j.foar.2014.10.001.

[6] L. Penta, "Paradigma antara teori makna hersberger dan teori keindahan vitruvius terhadap ekspresi estetika sebuah objek arsitektur," pp. 1-19, 2015.

[7] A. Dey, M. Billinghurst, R. W. Lindeman, and J. E. Swan, "A systematic review of 10 Years of Augmented Reality usability studies: 2005 to 2014," Front. Robot. Al, vol. 5, no. APR, 2018, doi: 10.3389/frobt.2018.00037.

[8] E. Redondo, D. Fonsecab, A. Sáncheza, and I. Navarroa, "New strategies using handheld augmented reality and mobile learningteaching methodologies, in architecture and building engineering degrees," Procedia Comput. Sci., vol. 25, pp. 52-61, 2013, doi: 10.1016/j.procs.2013.11.007.

[9] J. M. Laurens and G. Tanuwidjaja, "Melalui Pendekatan Desain Inklusi Menuju Arsitektur Yang Humanis," 2012, [Online]. Available: http://repository.petra.ac.id/15803/.

[10] J. Anderson, Basics Architecture 03: Architectural Design. 2018.

[11] Timothy L hemsath, "Conceptual Energy Modeling For Architecture, Planning And Design : Impact Of Using Building Performance Simulation In University Of 
Nebraska-Lincoln," Proc. BS2013 13th Conf. Int. Build. Perform. Simul. Assoc. Chambéry, Fr. August 26-28, pp. 376-384, 2013, [Online]. Available:

http://www.ibpsa.org/proceedings/BS2013/ p_2015.pdf.

[12] A. Asadpour, "Studies Defining the Concepts," Nature, vol. 7, 2020.

[13] P. Hidayat, "Menjelajah Candi Borobudur di Saat PSBB," 2020.

https://www.goodnewsfromindonesia.id/20 20/04/10/menjelajah-candi-borobudur-disaat-psbb (accessed Jun. 15, 2021).

[14] A. M. Ridjal, "Membangun Jembatan Antara Buku Dan Praksis Arsitektur," Rev. Urban. Archit. Stud., vol. 10, no. 2, pp. 95-103, 2012, doi: 10.21776/ub.ruas.2012.010.02.9.

[15] M. Metode, R. Arsitek, and N. Cross, "TINJAUAN ARSITEKTUR : BAGAIMANA MERANCANG ARSITEKTUR DAN MERANCANG : Menerjemahkan ke dalam bahasa rupa ( ruang - bentuk ) Merangkai dan merakit unsur ruang - bentuk," vol. 12, no. 3, pp. 35-43, 2015.

[16] F. Abidzar, "Ekplorasi Program Ruang Sebagai Aspek Redefinisi Penjara," vol. 8, no. 2, pp. 2-6, 2019.

[17] IAI, "Pedoman Hubungan Kerja Antara Arsitek Dengan Pengguna Jasa Ikatan Arsitektur Indonesia," Jakarta, 2007.

[18] J. Peddie, Augmented Reality: Where We Will All Live, vol. 2018, no. January. Springer International Publishing Switzerland, 2012.

[19] I. De A. Souza-Concilio and B. A. Pacheco, "The development of augmented reality systems in informatics higher education," Procedia Comput. Sci., vol. 25, pp. 179-188, 2013, doi: 10.1016/j.procs.2013.11.022.

[20] P. Cipresso, I. A. C. Giglioli, M. A. Raya, and G. Riva, "The past, present, and future of virtual and augmented reality research: A network and cluster analysis of the literature," Front. Psychol., vol. 9, no. NOV, pp. 1-20, 2018, doi: 10.3389/fpsyg.2018.02086.

[21] J. Grubert and R. Grasset, Augmented Reality for Android Application Development. 2013.

[22] Y. Y. J. ; Y. Anshori, "TEKNOLOGI AUGMENTED REALITY," 2018 Fourth Int. Conf. Comput. Commun. Control Autom., pp. 36-48, 2016.

[23] D. A. Kusumawati, "PENGEMBANGAN VIRTUAL REALITY PADA LAWANG SEWU
SEBAGAI PENGENALAN OBJEK WISATA JAWA

TENGAH," Universitas Negeri Semarang, 2017.

[24] D. Ben Ghida, "Augmented reality and virtual reality: $A 360^{\circ}$ immersion into western history of architecture," Int. J. Emerg. Trends Eng. Res., vol. 8, no. 9, pp. 6051-6055, 2020, doi: 10.30534/ijeter/2020/187892020.

[25] Bramasta Putra Redyantanu, "Studi Perbandingan Implementasi Ar \& Vr Dalam," vol. 2, no. 2, pp. 109-116, 2020.

[26] H. A. Banwell, H. Uden, N. Marshall, C. Altmann, and C. M. Williams, "The iPhone Measure app level function as a measuring device for the weight bearing lunge test in adults: A reliability study," J. Foot Ankle Res., vol. 12, no. 1, pp. 1-7, 2019, doi: 10.1186/s13047-019-0347-9.

[27] H. Vitono, H. Nasution, and H. Anra, "Implementasi Markerless Augmented Reality Sebagai Media Informasi Koleksi Museum Berbasis Android (Studi Kasus : Museum Kalimantan Barat)," Univ. Tanjungpura Pontianak, vol. 2, no. 4, pp. 239-245, 2016.

[28] K. Kirchbach and C. Runde, "Augmented reality for construction control," Proc. Int. Conf. Inf. Vis., no. January, pp. 440-444, 2012, doi: 10.1109/IV.2012.76.

[29] T. Fukuda, K. Yokoi, N. Yabuki, and A. Motamedi, "An indoor thermal environment design system for renovation using augmented reality," J. Comput. Des. Eng., vol. 6, no. 2, pp. 179-188, 2019, doi: 10.1016/j.jcde.2018.05.007.

[30] R. Mendes Correia, A. Paio, and A. L. Soares, "Architectural Design Digital Change: Interactivity policy," no. Table 1, pp. 10911097, 2018, doi: 10.5151/sigradi2018-1673.

[31] C. Wagner, "70 Jobs for 2030," Futurist, no. February, p. 31, 2011.

[32] B. Lawson, How Designers Think. Burlington: Elsevier, 2005. 